\title{
A Life-threatening Complication of Acupuncture Theraphy: Bilateral Pneumothorax
}

\section{Akupunktur Tedavisinin Hayatı Tehdit Eden Komplikasyonu: Bilateral Pnömotoraks}

Tayfun Kermenli', Cebrail Azar ${ }^{2}$

\section{Abstract}

One of the potential complications of acupuncture is pneumothorax, caused by the entry of the needle to the visceral pleura and damaging the lung parenchyma. Our patient suffered a bilateral pneumothorax and sudden respiratory failure. Our intention in this study is to offer a reminder of this rare and life threatening complication with this case report. A 51 year-old male patient presented to the emergency department with dyspnea after acupuncture treatment at a hotel spa center. A physical examination revealed no respiratory sound in either lung. A chest $X$ ray revealed a bilateral pneumothorax. The patient was treated with a bilateral tube thoracostomy.

Key words: latrogenic, pneumothorax, acupuncture, tube thoracostomy, chest tube.

\section{Özet}

Akupunkturun komplikasyonlarından biri, iğnenin viseral plevraya ulaşması ve akciğer parankimine zarar vermesi sonucu oluşan pnömotorakstır. Acil servise başvuran hastamızda bilateral pnömotoraks ve ani solunum yetmezliği vardı. Bu olgu sunumu ile nadir görülen ve hayatı tehdit eden komplikasyonu hatırlatmayı amaçladık. Elli bir yaşında erkek hasta, bir otel spa merkezinde akupunktur tedavisi sonrası acil servise nefes darlığı şikayeti ile başvurdu. Fizik muayenesinde her iki akciğerde de solunum sesi alınamadı. Çekilen akciğer grafisinde bilateral pnömotoraks saptandı ve hasta bilateral tüp torakostomi ile tedavi edildi.

Anahtar Sözcükler: lyatrojenik, pnömotoraks, akupunktur, tüp torakostomi, göğüs tüpü.
'Department of Thoracic Surgery Clinic, Medicalpark Elaziğ Hospital, Elazığ, Turkey

${ }^{2}$ Department of Chest Diseases Clinics, Medicalpark Elaziğ Hospital, Elazı̆̆, Turkey
'Medicalpark Elazığ Hastanesi, Göğüs Cerrahisi Kliniği, Elazığ

${ }^{2}$ Medicalpark Elazığ Hastanesi, Göğüs Hastalıkları Kliniği, Elazığ

Submitted (Başvuru tarihi): 04.1 1.2019 Accepted (Kabul tarihi): 14.02.2020

Correspondence (iletişim): Tayfun Kermenli, Department of Thoracic Surgery Clinic, Medicalpark Elaziğ Hospital, Elazığ, Turkey

e-mail: tayfunkermenli@gmail.com 
Pneumothorax should be considered first in patients presenting to the emergency department with respiratory distress. It can be classified as spontaneous or traumatic pneumothorax, depending on its etiology (1). latrogenic pneumothorax is evaluated in the traumatic pneumothorax group, and its incidence is higher than spontaneous pneumothorax (2). It is most commonly seen after a transthoracic needle biopsy (24\%), subclavian vein catheterization (22\%), thoracentesis (20\%), a transbronchial lung biopsy (10\%), pleural biopsy (8\%) and positive pressure ventilation (7\%) (3). The incidence of iatrogenic pneumothorax following acupuncture is reported to be 0.87 in every 1,000,000 acupuncture treatments, and 1.75 in anatomical regions close to the thoracic cavity (4). We present the case of a patient who was diagnosed with bilateral pneumothorax due to respiratory distress in our emergency department.

\section{CASE}

A 51 -year-old male patient presented to our emergency department with dyspnea. A physical examination revealed no respiratory sound in either lung and the patient was cyanosed. Ecchymotic areas were noted on the skin in the lateral region of the vertebral column and in the medial region of the scapula resulting from cup therapy and acupuncture needles (Figure 1a). The pulse count was $103 / \mathrm{min}$ and the respiratory rate was 17 . Oxygen saturation in the room air was $86 \%$ and blood pressure was $95 / 45 \mathrm{mmHg}$. An anamnesis taken from the relatives of the patient revealed that the patient had undergone cup therapy and acupuncture in a hotel spa 1 hour previously for the treatment of back pain. Blood samples were obtained from the patient for cardiac tests and the EKG was observed. The $\mathrm{pH}$ of the patient's blood gas was 7.23, $\mathrm{PCO}_{2}: 58 \mathrm{mmHg}, \mathrm{PO}_{2}: 67 \mathrm{mmHg}$. Budesonidefluticasone nebulization was initiated in the emergency room due to the patient's history of asthma. An urgent chest X-ray was performed with a portable bedside device, revealing bilateral pneumothorax (Figure $1 \mathrm{~b}$ ).

The green colored angiocate (18G) was entered into the thoracic cavity to decompress the air, and $80 \mathrm{mg}$ prednisolone was given intravenously to prevent re-expansion edema in the lung. Bilateral chest tubes were inserted by a thoracic surgeon, and the patient was subsequently taken to the intensive care unit. There was minimal air leak from the left thorax tube. No air leakage was noted from the thorax drain in the 2 days following the insertion of the thorax tube, and both lungs were expanded (Figure 2). The right thorax drain was removed on the third day and the left thoracic drain was removed on the fourth day, and the patient was discharged as cured. A chest x-ray was found to be normal in an outpatient clinic control one month later.

\section{DISCUSSION}

Acupuncture and cup therapy are popular alternative therapies around the world for the treatment of various ailments, although it has no scientific basis. In many case reports published in literature, side effects such as pain, fatigue, bleeding, vasovagal syncope and numbness resulting from acupuncture have been described $(5,6)$. More serious complications that have been reported include pneumothorax, central nervous system injury, infection, epidural hematoma, subarachnoid hemorrhage, cardiac tamponade, gallbladder perforation, hepatitis and death. The most common of these serious complications is iatrogenic pneumothorax $(7,8)$, as with our case, and sometimes these complications can have fatal consequences. Re-expansion edema following the insertion of a thorax tube as a pneumothorax treatment is a significant problem. The main reason for decompression in our patient was to prevent any re-expansion edema that may occur in the lung. In the present case, steroid treatment for re-expansion edema prophylaxis was also given, although there are limited studies in literature on this topic (9).

Merchart et al. (10) carried out a study of 97,733 patients, in which serious side-effects were seen in six patients. Suicidal ideation in a 36-year-old man diagnosed with chronic depression, hypertensive crisis in a 66-yearold female patient with ischemic stroke history, vasovagal syncope in a 51-year-old man, acute asthma attack in a 62 -year-old woman with an asthma history, and two women, aged 43 and 73, reported that pneumothorax developed during needle processing.

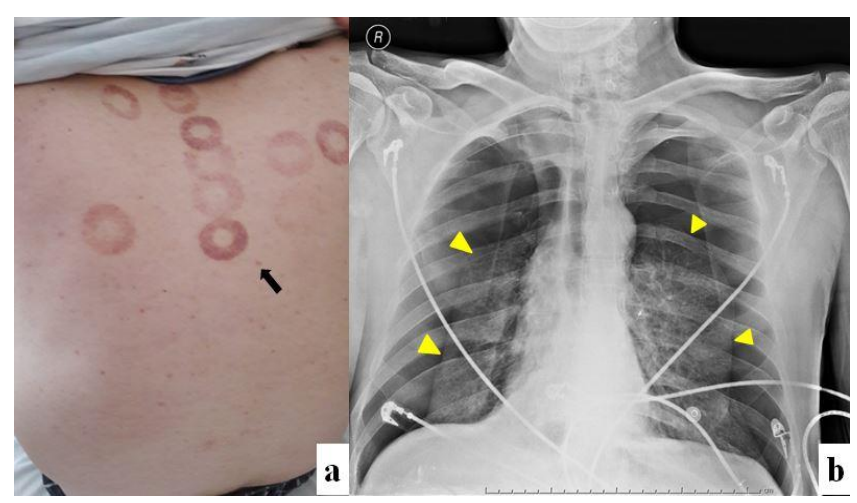

Figure 1: Patient photo shows acupuncture needle entries (black arrow) and ecchymotic areas resulting from cup therapy (a), AP Chest X-ray showing the bilateral pneumothorax (yellow arrowhead) (b) 


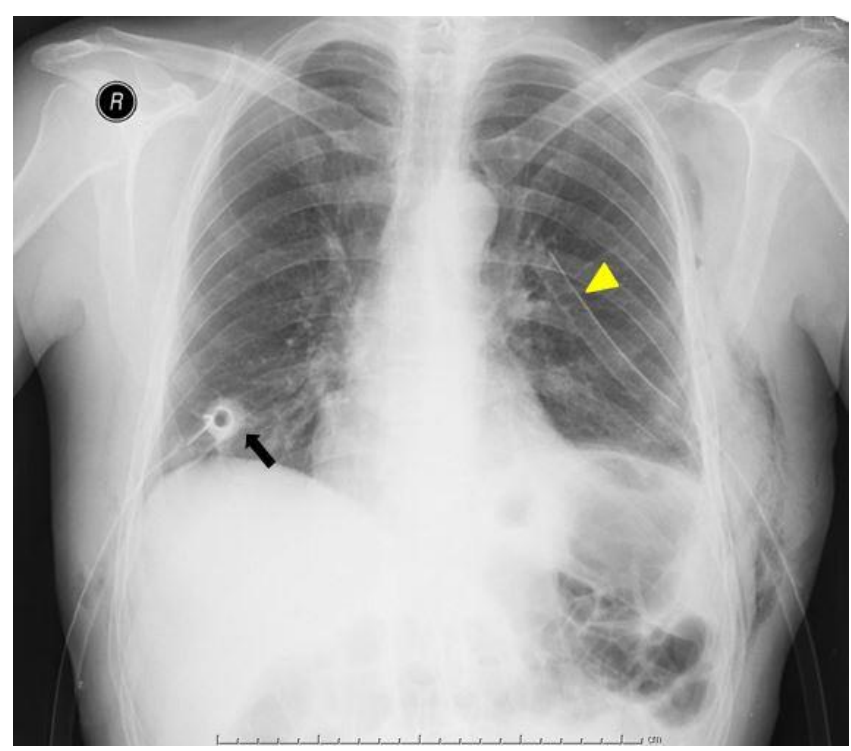

Figure 2: Chest X-ray showing thorax tubes in the right (black arrow) and left hemithorax (arrowhead)

A case report published by Hampton et al. (11) detailed a 43-year-old female patient with chronic neck pain for which a chest tube insertion was not necessary as a result of high volume oxygen therapy. The authors also stated that the area between the posterior edge of the scapula and the vertebra was a risky site for pneumothorax. Jian et al. (12) reported a case diagnosed with postmortem pneumothorax after acupuncture application. As stated in literature, acupuncture can be sufficiently dangerous to be potentially lethal. This suggests that acupuncture may have serious complications and should be performed only by specialist health professionals.

\section{CONCLUSION}

latrogenic pneumothorax should be kept in mind in patients presenting to the emergency department with dyspnea. As the first diagnostic method, anamnesis and physical examination followed by chest radiography are usually sufficient. Treatment usually requires chest tube insertion, but in the presence of tension pneumothorax, decompression with green or gray angiocet (16-18 G) may be used to relieve the patient's breathing until the chest tube is inserted. Close follow-up and high volume oxygen supplementation may considered as a treatment option in patients with a small pneumothorax.

\section{CONFLICTS OF INTEREST}

None declared.

\section{AUTHOR CONTRIBUTIONS}

Concept - T.K., C.A.; Planning and Design - T.K., C.A..; Supervision - T.K., C.A.; Funding - T.K.; Materials - T.K.,
Y.P.G., N.K.; Data Collection and/or Processing - T.K., C.A.; Analysis and/or Interpretation - C.A.; Literature Review - T.K., C.A.; Writing - T.K.; Critical Review - T.K., C.A.

\section{YAZAR KATKILARI}

Fikir - T.K., C.A.; Tasarım ve Dizayn - T.K., C.A.; Denetleme - T.K., C.A.; Kaynaklar - T.K.; Malzemeler - T.K.; Veri Toplama ve/veya İsleme - T.K., C.A.; Analiz ve/veya Yorum - C.A.; Literatür Taraması - T.K., C.A.; Yazıyı Yazan - T.K.; Eleştirel İnceleme - T.K., C.A.

\section{REFERENCES}

1. Swierzy $M$, Helmig M, Ismail M, Rückert J, Walles $T$, Neudecker J. Pneumothorax, Zentralbl Chir 2014; 139(Suppl 1):S69-86. [CrossRef]

2. Özturan IU, Doğan NÖ, Alyeşil C, Pekdemir M, Yılmaz S, Sezer HF. Factors predicting the need for tube thoracostomy in patients with iatrogenic pneumothorax associated with computed tomography-guided transthoracic needle biopsy. Turk J Emerg Med 2018; 18:105-10. [CrossRef]

3. Noppen M, De Keukeleire T. Pneumothorax. Respiration 2008; 76: 121-7. [CrossRef]

4. Lin SK, Liu JM, Hsu RJ, Chuang HC, Wang YX, Lin PH. Incidence of iatrogenic pneumothorax following acupuncture treatments in Taiwan. Acupunct Med 2019; 37:332-9. [CrossRef]

5. Öncel M, Tezcan B, Sunam GS. latrogenic bilateral pneumothorax after acupuncture. Respir Case Rep 2013; 2:158-9. [CrossRef]

6. Özgen E, Bozkaya Yücel B, Yücel M, Güzel M, Gürgün $K E$, Yürümez Y. A rare complication after acupuncture: pneumothorax. Geleneksel ve Tamamlayıc Anadolu Tıbbı Dergisi 2019; 1:1-4.

7. Tucciarone M, Taliente S, Gómez-Blasi Camacho R, Souviron Encabo R, González-Orús Álvarez-Morujo R. Extensive pyomyositis of prevertebral muscles after acupuncture: Case report. Turk J Emerg Med 2019; 19:113-4. [CrossRef]

8. Huisma F, Konrad G, Thomas S. Pneumothorax after acupuncture. Can Fam Physician 2015; 61:1071-3.

9. Kepka S, Lemaitre L, Marx T, Bilbault P, Desmettre T. A common gesture with a rare but potentially severe complication: Re-expansion pulmonary edema following chest tube drainage. Respir Med Case Rep 2019; 27:100838. [CrossRef]

10. Melchart D, Weidenhammer W, Streng A, Reitmayr S, Hoppe A, Ernst $E$, et al. Prospective investigation of ad- 
verse effects of acupuncture in 97733 patients. Arch Intern Med 2004; 164:104-5. [CrossRef]

11. Hampton DA, Kaneko RT, Simeon E, Moren A, Rowell S, Watters JM. Acupuncture-Related Pneumothorax. Med Acupunct 2014;26:241-5. [CrossRef]
12. Jian J, Shao Y, Wan L, Zhang M, Liu N, Zhang J, et.al. Autopsy diagnosis of acupuncture-induced bilateral tension pneumothorax using whole-body postmortem computed tomography: A case report. Medicine (Baltimore) 2018; 97:e13059. [CrossRef] 